\title{
The Russian Language in the Socio-Cultural Adaptation of Kurds Who Resettled to the Republic of Adygea
}

\author{
Alla Nikolaevna Sokolova \\ Asiet Yusufovna Shadje \\ Federal State Budget Institution of Higher Professional Education «Adyghe State University» (ASU) \\ 385000, Maikop, street Pervomayskaya, 208, Russian Federation; Email: nisadgu@yandex.ru
}

\section{Doi:10.5901/mjss.2015.v6n5s2p283}

\begin{abstract}
Migration flows, which have significantly altered the demographic composition of the South of Russia over the last 25 years, are connected with the inflow of population with poor knowledge of the Russian language. One of the numerous ethnic groups that compactly settled in the Krasnogvardeysky District of the Republic of Adygea is the Kurds (more than 5,000 people). According to the census of the Russian Federation in 2010, every 13th Kurd in Adygea did not speak Russian. In a multiethnic environment, which is characteristic of the Republic of Adygea, the Russian language plays an important unifying role. It largely provides the political stability of the region, true friendship of peoples, and tolerance towards different cultures. Most materials were obtained by researchers in the course of three years of work with the Kurds of Adygea, numerous interviews with people of different ages and occupations, and due to studying the official documents of the administrations of rural settlements and observation of the behavior of students in school and ordinary people in everyday life. The authors used statistical, logical, and sociometric techniques and methods of interdisciplinary research considering the Kurdish ethnic group from the standpoint of sociology and cultural anthropology, as well as the method of participant observation, which allows stating changes that occur in the development of ethnic groups. The Kurds of Adygea demonstrate high conservation of their verbal native language, but least of all are interested in obtaining a good education, knowledge of the Russian language, which does not contribute to successful adaptation and creates certain social risks. Supporting the position of preservation and development of the native language, we are convinced that the knowledge of the Russian language as the state and world language is the norm for all Russians, and its rapid learning by settlers and their children will contribute to the successful future of the entire ethnic group. The value of the Russian language in contemporary Russia is not confined to the fact that it is a state language in modern Russia. In the country where more than hundred nations live, the Russian language is the language of interethnic communication and it is recognized by the UN as the world language. Any document of the UN among other seven world languages should be necessarily translated into Russian. The richness of the Russian language is supported by a large number of artistic, scientific and political literatures, which has received an international recognition. And today the Russian language remains the repository of national, historical, cultural, and spiritual heritage of not only the ethnic Russians, but also of all Russian nationals.
\end{abstract}

Keywords: the Kurds of Adygea, Russian language, adaptation, migrants

\section{Introduction}

The number of Russian speakers has been reducing in the Russian Federation since the collapse of the Soviet Union. Migration flows, which have significantly altered the demographic composition of the South of Russia, were also connected with an inflow of population poorly speaking or not speaking the Russian language. This situation is fraught with certain social risks, and in no way contributes to the successful adaptation of the new settlers. In the multiethnic environment, which is characteristic of the Republic of Adygea (more than a hundred ethnic groups live in the Republic), the Russian language plays an important unifying role. No state can exist without the state language ensuring the harmonious functioning of the community and favorable communication. Knowledge of the state language is not only desirable, but also a prerequisite for the country's inhabitants. Since recently, new migrants from Ukraine, Syria, and Turkey are obliged to pass the exam in the knowledge of the Russian language for a residence permit or a work visa. This requirement had not been produced to the settlers who arrived to the Republic of Adygea in the 1990s, and a large Kurdish subgroup, marginal in terms of its involvement in social and cultural life of the society due to poor knowledge/ignorance of the Russian language formed in the region. It was found that the ignorance of the state language adversely affects not only the status of the ethnic group, its competitiveness, its social mobility, but also is fraught with 
social conflicts, lack of mutual understanding at all levels of the system of social relations, emergence of phobias and dislikes, predictive social anxiety. Scientists' concern with the reducing knowledge of the Russian language in the Republic arises from the analysis of the language situation in schools, where children of the Kurdish settlers study, and identification of the value references of the Kurdish youth for whom education is not of the paramount importance in life. Discussion of the specified problems is the essence of this article.

\section{Materials and Methods}

The article presents the materials obtained in the course of three years of work with the Kurds of Adygea. Members of the research group had the opportunity to travel to the villages of the Krasnogvardeisky District of the Republic of Adygea, where more than 5,000 Kurds live who migrated to the Republic 20-25 years ago. The main part of materials were obtained by the researchers through interviews with the Kurds of all ages and professions and representatives of the oldRussian population by studying the official documents of the administrations of rural settlements and observance of the behavior of students in school and ordinary people in everyday circumstances.

Statistical, logical, and sociometric techniques and methods of interdisciplinary research considering the Kurdish ethnic group from the standpoint of sociology and cultural anthropology were used, as well as the method of participant observation, which allows stating the changes occurring in the development of ethnic groups.

\section{Discussion}

One of the achievements of the Soviet Union was the literacy rate, largely due to the knowledge of the Russian language and communion to the world culture through it. Virtually the entire population of the country- a little more than 280 million people-spoke Russian by the time of the Soviet Union collapse. 145 million people considered the Russian language native. After the collapse of the Soviet Union the position of the Russian language began to decline steadily. According to forecasts of the Center for Social Research of the Russian Ministry of Education and Science, by 2025 the number of people speaking Russian in Russia will decrease to 110 million persons (Arefiev, 2012).

According to the census of 2002 in Russia, 142.6 million persons spoke Russian, and at the census of 2010, the number decreased to 138 million persons (99.4\% of the population). On the one hand, it confirms once again that the role of the Russian language is quite large in the life of the Russian society. On the other - it is not yet possible to reverse the downward trend in the number of Russian-speakers.

Scientists of different specialties are trying to understand the reasons for this trend. Many of them agree that the main reason is the natural decline in population, high mortality, which was typical of the 1990s. Partially, the decline in the number of the Russian-speaking population is associated with former Soviet citizens who were born in the post-Soviet era and have not received proper education and who migrate to Russia. The language experiences certain negative impacts under the influence of globalization.

The purpose of this article is to prove the importance of the knowledge of the Russian language for Russian citizens and for the future of the country. This is especially relevant for migrants who have not so long ago moved to the Russian Federation. In particular, we are talking about the Kurdish migrants who have settled in the Republic of Adygea.

The value of the Russian language is not confined to the fact that it is a state language in modern Russia. In a country where more than hundred nations live, the Russian language is the language of interethnic communication and is recognized by the UN as a world language. Any document of the UN among other seven world languages should be necessarily translated into Russian. The richness of the Russian language is supported by a large number of artistic, scientific, and political literature works, which have been recognized internationally. And today the Russian language remains the repository of national, historical, cultural, and spiritual heritage of not only the ethnic Russians, but also all Russian nationals.

In this regard, it is important to analyze the importance of the Russian language for the Kurdish ethnic group in Adygea, which is the fifth-largest group in the demographic map of the country. The relevance of this analysis is related to the attitude of immigrants from the former Soviet republics towards the state language. Some of them were born in the post-Soviet era, their socialization took place in the linguistic environment of the national republics (Armenia, Azerbaijan, Kazakhstan, and Kyrgyzstan), that is why many of the Kurds in Adygea are fluent in not only the native language, but also Armenian, Azerbaijani, Kyrgyz. Children born in Adygea were mostly (and sometimes exclusively) brought up in the Kurdish language environment before going to school. Therefore, many of them go to school without any knowledge of the Russian language, which invariably affects the quality of education. The children of Kurdish immigrants learn the lexical scope of the Russian language necessary for understanding the educational requirements and tasks only by the 
seventh grade. They undoubtedly cannot pursue a program in primary school, since the children are just beginning to gain a minimum vocabulary for the communication.

The Kurds of the older generation, mainly engaged in housekeeping and agricultural cultivation in home gardens, are also within the native language environment. Russian language is not only much needed for them, but it is not necessary in any degree. This is especially true for women who do not leave the house unaccompanied by their husbands or brothers, and all social interaction outside the Kurdish community (visiting the village administration, tax authorities, schools, citizens' assemblies) is entrusted to men. The life support sphere is "served" only by means of the native language. Moreover, almost all Kurdish families have TV sets tuned to the Kurdish broadcasters in Belgium, Germany, Turkey, so the spiritual component of their culture is also filled with the native language.

The difficulty in mastering the Russian language is directly linked to three main reasons: 1 ) the compact settlement of Kurds in the same area, and the compact settlement in villages, in one street or one block; 2) the agricultural work in their backyards and non-inclusion in the work of any public or commercial establishments and manufactures; 3 ) the virtual absence of urban residents and intellectuals as a social group among the Kurds of Adygea (individual persons or families are an exception to the general rule).

Men involved in the sale of agricultural products grown by Kurds (onions, zucchini, peppers, tomatoes) mainly become the "guides" for the Kurds to the multicultural space of Adygea and Russia as a whole.

The described situation as a whole creates a very tangible cultural distance between immigrants and representatives of the host country. There is no doubt that not only the language or attitude to the language serve as indicators of distance. However, we focus on the language issue, as we understand its importance and significance.

A priori supporting a position of preservation and development of the native language, we are also convinced that knowledge of the Russian language as the state language and the world language is the norm for all Russians, and its rapid and successful learning by migrants and their children will contribute to the successful adaptation of the entire ethnic group of Kurds and reveal a successful future to them.

\section{Characteristics of the Language}

Language is the home of human existence. The human exists in the language and at the language. It is the language environment that raises the human, feeds and determines his thinking and culture. It also forms the personality.

The language is a system of signs, which serves as a means of communication, thinking, and expression. With the help of the language a person learns the world, expresses his attitude to it. This suggests that the language and thought of the person are internally united. German philosophers Herder and Humboldt indicate the unity of the thought and the language. "The human thinks, feels, and lives only in the language; he must first be formed by means of the language in order to learn to understand the art acting in addition to the language. But the human feels and knows that the language is only a means for him, that there is an invisible world beyond the language, to which the human strives to settle with only its help" (Humboldt, 1985).

Thus, language is an essential element of the human person, "the bearer" of the human mind, a means of expressing the personality. It is proved that a specific language is the material bearer of the thought. The language, in which person thinks, is considered to be native.

It is important to note another important feature of the language. It is not an isolated phenomenon, but exists in a dialectical relationship with the culture of the ethnic group. Russian thinker of the nineteenth century, Potebnia, saw the mechanism generating thought in the language. The idea is manifested through the language, and every act of speaking is a creative process, which does not repeat the already finished truth, but gives birth to the new one. He emphasizes that "the language is a means not for expressing a ready-made thought, but for its creation, that it is not a reflection of the prevailing world view, but the component of its activities" (Potebnia, 1989). The language is what determines the ethnic specificity of a human, the ethnic vision of the world, or, as they say, the mentality.

The language is not only connected with the sphere of social consciousness, but also with sociocultural and ethnic spheres. On the one hand, the language appears as the value of the people, on the other, it is impossible to understand the ethnic values, the soul of the people, the mentality without it.

Indeed, the language of any nation is not only a means of communication. The language creates, produces the spiritual life of the ethnic group. Firstly, a thing without name does not exist. As aptly noted by Academician Likhachev, if we do not say the word, a living reality behind it dies. The result is a drop of culture.

Secondly, in the words of Iliin, "There is a law of human nature and culture, by virtue of which all great can be said by a person or people only in his/their own way, and everything genius is born in the bosom of the national experience, spirit and way of life" (lliin, 1992). It follows that a kind of "cultural genes" are laid down in the language. The ethnic 
language also includes such cultural phenomena that have become symbols of the spiritual life of the people, their value.

\section{The Language Situation the Ethnic Group of Kurds of Adygea}

One of the pressing problems faced by Kurdish settlers in the process of sociocultural adaptation is the knowledge of the Russian language. According to the 2010 census of the Russian Federation, every $13^{\text {th }}$ Kurd in Adygea does not speak Russian (Results of the census, 2010).

Students face even more problems in the field of the language. Problems of school education, in particular, the serious problems with the Russian language of the children of Kurds settlers were discussed at the round table as part of our research project (Proceedings of the Round Table, 2012). Serious problems with the Russian language are common for students of lower grades. According to the school personnel participating in the round table, the vast majority of Kurdish children do not attend pre-school establishments, which also has a negative impact on their knowledge of the Russian language. This situation is compounded by the fact that students Kurds make up the majority in some schools of the district. The problem with the knowledge of the Russian language is characteristic for adolescent girls who marry at 14-15 years of age and drop out of school in the higher grades (Sokolova, 2012).

The native language of Kurds took over the most important feature of ethnic integration. Deprived of their state, the Kurds are everywhere in the position of a diaspora. Often, they are not united in any other communities, except for ethnic. The Kurds of Adygea, as well as the Kurds of the Krasnodar, Stavropol, and Saratov Regions, etc. have community organizations formed according to the ethnic principle. The high status of the native language has emerged and entrenched due to this fact. It has absorbed all ethnic ideas, values, mental characteristics. Language, expressed through proverbs, tales, folk songs, supported by music, dancing, visual and behavioral, and other languages of culture, is volumetrically transmitted to each new generation, remaining mostly verbally. Only a few persons have a good command of the Kurdish written language and can use it on the Internet. The Kurds of Adygea demonstrate high conservation of the verbal native language, high enough to see no need to add lessons of the native language to the school program.

It should be noted that the rational necessity of a critical attitude to their culture, achievements of its people and inclusion in the system of values of humanity has always occurred through bilingualism. The majority of Kurds living in the former Soviet Union and modern Russia have always been bilingual. However, they have been speaking the languages of the Caucasus (Armenia, Azerbaijan, and Turkey) for a long time. Transition to the Russian language is particularly difficult for them. Schoolteachers of the Krasnogvardeisky District of the Republic of Adygea note that the Adyghe language learning by the Kurds, which is mandatory for the students of the Republic, proceeds much simpler and faster than the learning of Russian. Pronunciation of hissing sounds is easier for them, a significant number of common words are found. As a rule, regional and republican Olympiads in the Adyghe language are attended by Kurdish children from the Krasnogvardeisky District of Adygea, not Russian. Nevertheless, the task of familiarizing Kurdish students with the Russian language is assigned to rural schoolteachers.

Teachers cannot replace family education, but only complement it. If children do not have tolerant conscious, a sense of the need to expand their value-related and worldview references, their outlook and attitude, to understand the "other person", standing side by side through the study of the Russian language, then the "other" language, culture, etc. will remain strange/hostile to them. Our study confirmed that the degree of proficiency in Russian depends on the level of education of parents. Children, whose parents have secondary or higher education, demonstrate a high level of proficiency in Russian, and vice versa. On the other hand, Russian children studying in the same form with the Kurds and being the minority quickly learn the Kurdish verbal language and even act as interpreters between teachers and Kurdish students. In this case, Russian children understanding the Kurdish language become "their," "close" people, almost brothers for the Kurds. So it is clear that the language brings people together and creates an atmosphere of mutual trust and understanding.

\section{The Value of the Russian Language in a Multicultural Region}

Spiritual development of the people and formation of value-conscious and belief orientations are impossible without a deep knowledge of the Russian language, having different functions. The Russian language has its functioning peculiarities and a special role in regional life. Firstly, it is not only a means of communication for the multi-ethnic population of Adygea, but also the habitat, "the house of being," where people live, learn, work, etc. Secondly, the Russian language is the integrating basis for the strengthening of the Russian statehood. Thirdly, it is important to emphasize that the Russian language in a multilingual country does not displace other languages or impose its supremacy over other languages and operates in parallel. 
It is easy to notice that, on the one hand, the language is a mirror reflecting political, economic and social changes, and on the other, a particular socio-historical and socio-political situation affects the functioning of the language. We learned this through the example of the languages of the former Soviet Union, including the Russian language.

In the late 1980s, the Soviet Union, in the words of the Russian philosopher Florenskii, reminded the Babylonian confusion of tongues when no one understood and heard each other, and every speech only served to finally certify and secure mutual alienation (Florenskii, 1990). The language has become an arena for score settling: the Russian language was opposed to the languages of other ethnic groups.

Meanwhile, the reality is that the Russian language was not only the language of official structures, but also the language of culture, science, the language of interethnic communication in the country, and a channel for the release of cultures of many nations on the world stage. As the language of a great culture, it has become the language of communication not only for the Russians, but also for other nations. We have the ability to communicate with each other, to learn the history and culture of different nations in Russian.

Motroshilova notes quite rightly that "Kazakhs, Uzbeks, Tajiks, Latvians, Lithuanians, Ukrainians, and other peoples of the former USSR can now communicate with each other in Russian. Therefore, the struggle against the Russian language driven by the politics in some parts of the post-Soviet space is an aggression, albeit clear in its origins, but anticivilizational in its essence, against the anything but guilty spiritual means of the culture. After all, knowledge of the language of a great culture is a special historical success, the neglect of which defies common sense" (Motroshilova, 2006).

The Russian language operates in a multi-ethnic society, as the foundation of coexistence and cooperation between peoples, as a basis for the development of the national culture, science, and education. This is very important because respect and understanding are only possible through knowledge.

\section{The Language Situation in Adygea in General}

In assessing the language situation in Adygea, we should note that the equal official languages in the Republic of Adygea are the Russian and Adyghe languages. The proclamation of the Adyghe language as state along with Russian does not mean the creation of priorities for the former, that the Circassians get some privileges. The historically formed sociocultural environment in Adygea, where representatives of more than 100 ethnic groups considering it their homeland live, has been forming a respectful attitude to the Russian language and laid the foundations of the national-Russian bilingualism. Furthermore, let us remember that the peoples of the North Caucasus, in particular, Circassians, have always sought to learn the Russian language. Their interest is shown by the fact that they often send their children, especially boys, to their Russian friends and acquaintances, so that children have mastered the Russian language. The Russian language played a big role in the training of competent national personnel in the first years of the Soviet rule. As a result, with the help of Russian scientists and educators, Circassians got their alphabet and developed the literary language.

Today, respectful perception and understanding of the "other"/another culture in the Republic have become possible due to the Russian language. The multi-ethnic population of Adygea, understanding the value and importance of the Russian language for their cultural development, seeks to multiply the traditions of mastering the Russian language. This does not mean that there are no problems in the language sphere. The Kurds have "plunged" in such a sociocultural environment 25 years ago.

It is known that development and implementation of social adaptation technologies, legal and economic mechanisms of integration into the host society, preservation and development of ethnic and cultural values are significant in the process of sociocultural adaptation of forced migrants. Therefore, the Russian language is rarely mentioned as a factor of sociocultural adaptation. It should be noted that in other ethnical and cultural environment, the role and importance of the Russian language increases. This is due to an important feature of the Russian language-it is a mean of social and cultural adaptation in a multicultural region.

As a result of the process of social and cultural adaptation, the influence of the Russian language on the adaptation is rarely noted. After all, an important indicator of the cultural change in the ethnic group, its openness and dialogueness is the knowledge of the Russian language.

The language environment is a nonlinear medium (system), in which different cultures coexist. Forceful intervention in the system destroys it. Where the force dominates, accompanied by the violent introduction of a culture and language, the "semiotic space", which forms the personality, is destroyed. It follows that the force cannot correct the situation, but it is impossible to watch passively. It is fraught with high risks of domestic conflicts, misunderstandings in communication, prevalence of negative attitudes towards the values of each other. Ultimately, ignorance/poor knowledge 
of the language of the host side prevents the successful adaptation of the Kurds in the multiethnic environment of Adygea.

Any settlers should show the value, attractiveness, rich possibilities of the Russian language, and it does not lead to Russification/unification of the ethnic. It is important to understand the meaning of the language-both native and Russian-as the identification markers.

Of course, the school should play and plays an important role in inclusion of the Kurds in the Russian language. The number of Kurdish children enrolled in 9-11 school grades has been increasing very slowly, but, nevertheless, notably in recent years. Non-accent Russian speech and qualitative mastering of the curriculum is already typical of them. Such children act as representatives on behalf of their family in the local administrations, explain the meaning of the official letters from the tax or the fiscal authorities to their parents, fill the required documents, applications, etc. There is a reason to believe that fluency in the Russian language makes the adaptation of all generations of the Kurds in the Republic of Adygea really successful. However, a profound mistake, in the opinion of members of the research group, which have been studying the designated issue for thee years, is the position of the majority of the host community and especially the officials of local governments and power structures of the republic that the settlers are unilaterally "obliged." "They have come here, so they must speak Russian," "They must not hold their celebrations on the streets," "They should do as the Romans do"-these and similar statements do not tune to the positive solution of any problems. How can a person be forced to learn a foreign language if all life support channels are "served" by their native language, and intellectual needs of the ethnic group are at a very low point? It is clear that in such a situation calls to learn the language and attend the courses sound as slogans. Over the 25-year tenure of the Kurds in Adygea, not a single group for language learning among adults has been formed.

In any multiethnic space, both dialogue and polylogue are important. Therefore, the presence of certain preferences, in our opinion, is important not only and not so much for the Kurds, but for the entire community. If in equal opportunities, for example, in the allocation of funds for the construction of childcare facilities, a choice is made in favor of the villages with a predominantly Kurdish population and admit Kurdish kids there, we will get the population prepared for school who speak Russian, and are ready to take the value of education through it, form a craving for creativity and intellectual activity. Moreover, it is kindergarten and school that have to teach children to recognize that the meaning of the Russian language in modern conditions is expanding and becomes more profound.

Drobizheva, under whose supervision numerous studies on the problems of identity and inter-ethnic relations in the republics of the Russian Federation have been conducted, concludes: "Even such a marker, as a language, is not purely cultural. Knowledge or ignorance of the Russian language for people of different ethnic groups in Russia is a road or a barrier to education, access to prime positions, which is usually interpreted as an exception" (Drobizheva, 2013).

\section{Conclusion}

A positive impact on the successful implementation of the sociocultural adaptation of Kurds in another ethnic environment and development of intercultural interaction in a multicultural region could have improved the command of the Russian language of Kurdish settlers. To do this, it is important to work on popularizing the Russian language among the Kurds through the media, local authorities, and extra-curricular club activities; to attract students to the Kurdish students to the festival movement within the Republic of Adygea and the Krasnodar Region. In other words, using all means of mastering the Russian language, to seek to learning and understanding each other. It appears that the equal coexistence and mutual understanding are possible only through an equitable intercultural dialogue, based on the Russian language.

It is important that the Kurdish population recognize the axiological importance of the Russian language for them, that the Russian language is not only the language of the ethnic Russians, not only a mean of communication with representatives of different ethnic groups, a means of understanding of other cultures. The Russian language is a common cultural value, based on which and through which the cultural distance between members of different ethnic groups is reduced. The Russian language is a sociocultural value, an important cultural and identifying marker, based on which the Russian nation and the Russian civil identity are formed. It is the force that unites us in culture, economics, politics, etc. The Russian language is a mean of preserving and strengthening our unity. It is the foundation of our peace and our mutual understanding. Therefore, all of us are connected with one desire and one objective-to preserve this unifying force, to strengthen our co-operation and unity of the country. The Russian language exists for us, the Russians, in the first place, and it receives its existence and development from us.

In the context of this problem, it seems necessary to unite the efforts of the state, educational, scientific and cultural institutions, public organizations, of all people, aimed at the implementation of new opportunities for the conservation, development, and dissemination of the Russian language. Today, it is important to understand the value of 
the Russian language, which is a unifying factor for Russian ethnic group, the Russian nation. The Russian language should help us realize our commonality, that we (regardless of ethnicity and religion) are the citizens of great Russia.

\section{Summary}

A positive impact on the implementation of successful sociocultural adaptation of Kurds in another ethnic environment and development of intercultural interaction in a multicultural region could have improved the command of the Russian language of Kurdish settlers. To do this, it is important to work on popularizing the Russian language among the Kurds through mass media, local authorities, and extra-curricular club activities and to attract the Kurdish students to the festival movement within the Republic of Adygea and the Krasnodar Region. It appears that the equal coexistence and mutual understanding are possible only through an equitable intercultural dialogue, based on the Russian language.

\section{Acknowledgement}

We are grateful to the Russian Humanitarian Foundation (RHF), which has provided a financial support to a group of scientists of the Adyghe State University at implementation of Project No. 12-06-00131 "Sociocultural Adaptation of the Kurds in the Republic of Adygea and the Prognostics of the Ethnic Group Development."

We are grateful to the rector's office of the Adyghe State University for their support in the publication of the article.

\section{References}

Arefiev, A.N. (2012). Russkii iazyk na rubezhe XX-KhKhl vekov [Russian language at the turn of XX-XXI centuries] (pp. 482). Moscow: Center for Social Forecasting and Marketing [in Russian].

Drobizheva, L.M. (Ed.) (2013). Grazhdanskaia, etnicheskaia i regional'naia identichnost': vchera, segodnia, zavtra [Civil, ethnic and regional identity: yesterday, today and tomorrow]. Moscow: Russian Political Encyclopedia [in Russian].

Florenskii, P. (1990). U vodorazdelov mysli [At the watersheds of thought] (Vol. 2). Moscow: Publishing House "Pravda" [in Russian].

Humboldt, V. (1985). lazyk i filosofiia kul'tury [Language and philosophy of the culture]. Moscow: Progress [in Russian].

Iliin, I.A. (1992). Put' dukhovnogo obnovleniia [The path of spiritual renewal]. Moscow: Publishing House "Respublika" [in Russian].

Motroshilova, N.V. (2006). Varvarstvo kak oborotnaia storona tsivilizatsii [Barbarism as the flip side of civilization]. Voprosy filosofii Problems of Philosophy, 2 [in Russian].

Problemy shkol'nogo i doshkol'nogo obrazovaniia i vospitaniia detei kurdov-pereselentsev v Respublike Adygeia» - Issues of School and Pre-School Education and Upbringing of Children of the Kurds Settlers in the Republic of Adygea: Proceedings of the Round Table (2012). Sokolova, A.N., Ed.. Maikop: Publishing House "OG Magarin" [in Russian].

Sokolova, A.N. (2012). Protsessy sotsial'no-kul'turnoi adaptatsii adygeiskikh kurdov v fil'me «Poznat' sebia» [The processes of sociocultural adaptation of Adyghe Kurds in the movie "Know thyself"]. Vizual'naia antropologiia: rossiiskoe pole - Visual Anthropology: Russian field: Proceedings of the Conference within the framework of the VI Moscow International Festival of Visual Anthropology "Mediating Camera". October 8-12, 2012, Alexandrov, E.V., \& Danilko, E.S., Eds. Moscow: IEA RAN [in Russian].

Potebnia, A.A. (1989). Slovo i mif [The word and the myth]. Moscow: Publishing House "Pravda" [in Russian].

The results of the National Population Census 2010. Retrieved 10.05.2014 from http://www.gks.ru/free_doc/new_site/perepis2010/crocl perepis__togi1612.htm [in Russian]. 